\title{
Congenital Clubfoot: A Comprehensive Review
}

\author{
Manisha Rani and Priyanka Kumari* \\ MM Institute of Nursing, Maharishi Markandeshwer University, India
}

Submission: July 19, 2017; Published: July 31, 2017

*Corresponding author: Priyanka kumari, Assistant Professor, MM Institute of Nursing, Maharishi Markandeshwar University, Mullana, Ambala, Haryana, India, Email: priyankakumari@mmumullana.org

\section{Abstract}

Although clubfoot (Congenital talipesequinovarus) is one of the most common congenital abnormalities affecting the lower limb with an incidence of one to two per 1000 live births, it remains a challenge not only to understand its genetic origins but also to provide effective longterm treatment. Its etiology remains aconundrum. It is increasingly being diagnosed on prenatal ultrasound with implications for prenatal counselling. The aim of the treatment is to obtain a painless and functional foot. Conservative treatment with Ponseti method of clubfoot is wellaccepted and has been reported to result in good correction ranging from as low as $50 \%$ to as high as $90 \%$. Surgical treatment is indicated only after failure of conservative methods, with limited release also known as "a la carte" release.

Objective: The aim of this review is to focus at etiology, clinical assessment, scoring and provides an overview of operative and non-operative treatment options.

Keywords: Clubfoot; Congenital Talipes Equinovarus; Genetic; Orthotic Device; Ponseti

\section{Introduction}

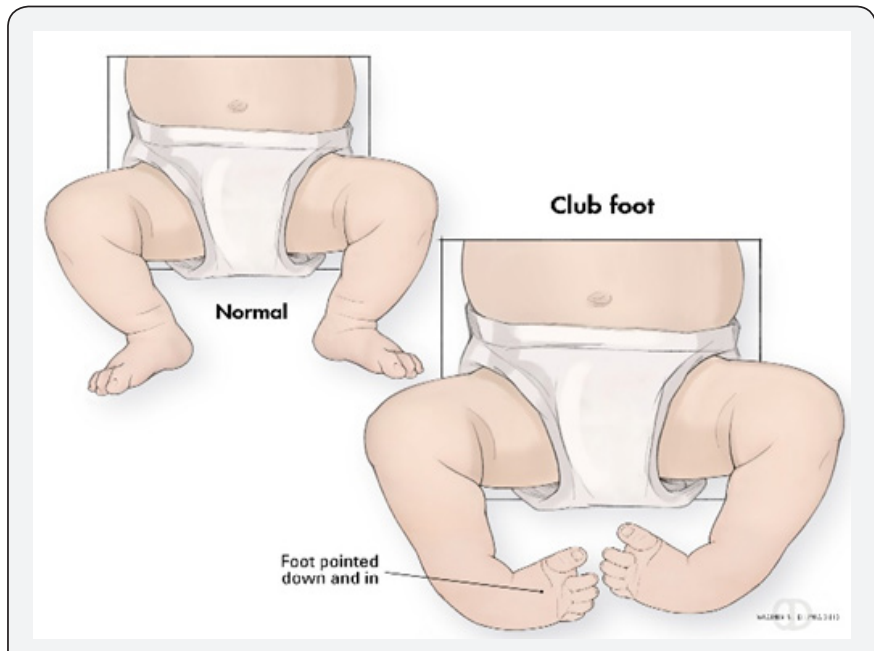

Figure 1: Comparison between normal foot and club foot.

Clubfoot or Congenital talipesequinovarus (CTEV) was introduced by Hippocrates around 300 B.C. He described two forms of clubfeet i.e. congenital and acquired in infancy. Term talipesequinovarus is originated from Latin word: talus (ankle) and pes (foot); equinus: "horse like" (the heel in plantar flexion) and varus: inverted and adducted. The incidence of congenital talipesequinovarusare about 1-2 per thousand live births. It is one of the most common birth defects involving musculoskeletal system (Figure 1).

The involvement is bilateral in about $50 \%$ of cases and in unilateral cases the right side is more commonly affected than left [1]. Idiopathic clubfoot occurs in males more often than in females by a ratio of 2:1.Clubfoot is an obvious deformity easily recognized. It has four classification: Equius, midfoot cavus, forefoot adduction and hind foot varus. When left untreated, children having clubfoot walk on the sides and/or top of their feet, which leads to callus formation, skin and bone infections, substantial limitation in mobility, reduced employment opportunities and inability to wear standard shoes. It is astonishing that in spite of the vast attention, there is still need to focus on its etiology and to identify the methods of assessment and treatment.

The deformity in idiopathic club foot is both cosmetic and functional with associated hypoplasia of skin, muscles, bones, tendons, ligaments and neurovascular bundle on the medial side and the affected foot is smaller than the normal foot [2]. Current treatment of clubfoot deformity includes initial trials of manipulation and serial casting. 30-50\% feet treated in this way eventually needs surgical correction [3]. The aim of the review is to provide an overview of clubfoot. 


\section{Etiology}

Club foot may be associated with myelodysplasia, arthrogryposis or many other congenital abnormalities but is more commonly an isolated idiopathic birth defect. Multiple theories have been put forward to explain its etiology.

\section{Mechanical Factors in Utero}

According to theory of Hippocrates, due to the compression of uterus, foot got the position of equinovarus. However, Parker and Browne believed that oligohydramnios restrict the movement of fetus [4].

\section{Neuromuscular Defect}

Some investigators maintain the opinion that equinovarus foot is always the result of neuromuscular defect [5]. On contrary, some studies of histological finding shows no abnormalities or no deformities [6].

\section{Primary plasma Defect}

Irani and Sherman had dissected 11 equinovarus feet and 14 normal feet and dissection revealed no any primary abnormalities of the nerves, vessels tendon and muscles insertions. Constantly the abnormalities were found in the anterior part of the talus. The talus was undersized and its anterior portion was medially rotated. They suggested that the deformity probably resulted from a primary germ plasma defect [7].

\section{Arrested Fetal Development}

a. Intrauterine environment: In 1863, Heuter and Von Volkman proposed that the early in embryonic life arrest of fetal development was a cause of congenital clubfoot [5].

b. Environmental influences: The harmful influence of teratogenic agents on fetal environment and development are well illustrated by the effect of rubella and thalidomide. Many authors believe that club foot and temporary growth arrest happens due to various environmental factors [8]. Honein et al. [9] reported the exposure of cigarette smoke and family history is associated with the causative factors for the club feet especially in Antenatal period [9].

\section{Polygenic theory of Hereditary Pattern}

Club foot tends to be familial in a significant number of cases. Wynne Davis supported the polygenic theory and showed a rapid decrease in incidence of clubfoot from first to second to third degree relatives. About $2.9 \%$ of siblings in the first degree relatives had this deformity as compared to 1-2 per thousand masses and chances of getting affected in siblings are more than 25 times [10].

\section{Classification}

The purpose of a classification system is to help in subsequent diagnosis and management. Various classifications of clubfoot exist in the literature. Dimeglio mentioned the different four categories of club foot, on basis of joint motion and ability to reduce the deformities [11].

i. Soft foot also called postural foot can be treated by physiotherapy and standard casting treatment.

ii. 2. Soft $>$ Stiff foot occurs in $33 \%$ of cases. It is usually a long foot which is more than $50 \%$ reducible and treated with casting and attain total correction of feet after 7-8 month, if not then surgery must required.

iii. Stiff $>$ Soft foot present in $61 \%$ of cases. It is less than $50 \%$ reducible after physiotherapy and casting. If specific requirements necessary, after the treatment then surgery can be performed.

iv. Stiff foot isteratologic and complex to rectify. It is in severe bilateral equinus deformity and requires a broad surgical improvement.

\section{Clinical Features}

Congenital clubfoot is differentiated by structural, postural and secondary type. The postural clubfoot can occur by abnormal position during birth and manipulative control. The patient should be thoroughly examined to assess the features of paralytic clubfoot. Congenital clubfoot can be rectifying completely.

\section{Diagnostic tests}

Table 1: Pirani scoring.

\begin{tabular}{|c|c|c|c|}
\hline Paramaters & Normal & Moderate & Severe \\
\hline $\begin{array}{c}\text { Midfoot } \\
\text { Curved lateral } \\
\text { border }\end{array}$ & 0 & 0.5 & 1 \\
\hline Medial crease & 0 & 0.5 & 1 \\
\hline $\begin{array}{c}\text { Talar Head } \\
\text { coverage }\end{array}$ & 0 & 0.5 & 1 \\
\hline Hind Foot & 0 & 0.5 & 1 \\
\hline $\begin{array}{c}\text { Posterior } \\
\text { crease }\end{array}$ & 0 & 0.5 & 1 \\
\hline Rigid equines & 0 & 0.5 & 1 \\
\hline Empty heel & & & \\
\hline
\end{tabular}

Increasingly, the diagnosis of clubfoot is being made on prenatal ultrasound examination, usually around 20 weeks gestation of babies with newly diagnosed clubfeet attending our institution; approximately two-thirds have been diagnosed prenatally. In other institutions, this figure may be as high as $77 \%$. Unsurprisingly, clubfoot is more likely to be detected prenatally if the condition is bilateral or if there are other anomalies present. As yet, the post-natal clinical severity of a true clubfoot cannot bededuced from the prenatal sonographic findings Pirani et al. Has developed a valid and reliable method of clinically assessment of the amount of deformity present in an unoperated congenital clubfoot less than 2 years of baby [12]. It allows the treating practitioner to know how patient is 
responding to treatment and when surgical cutting of tendon i.e. tenotomy is required [13] (Table 1).

\section{Radiological Assessment}

There are not any satisfactory methods of assessment by physician in the beginning of the deformity. Barwell (1896) introduced the plain radiographs to assess the exact status of clubfoot [2]. However, at birth, clinical examination is more informative than radiography. Tarsal bone seems like the small ball shaped ossicles. Thus, the plain radiograph film does not help to evaluate the shape and orientation of the tarsal. After three or four month ossification of tarsal bone occur and it became visible by radiological examination [14-19]. So there is no consensus on the value of radiographs in the routine management of congenital clubfoot (Figure 2).

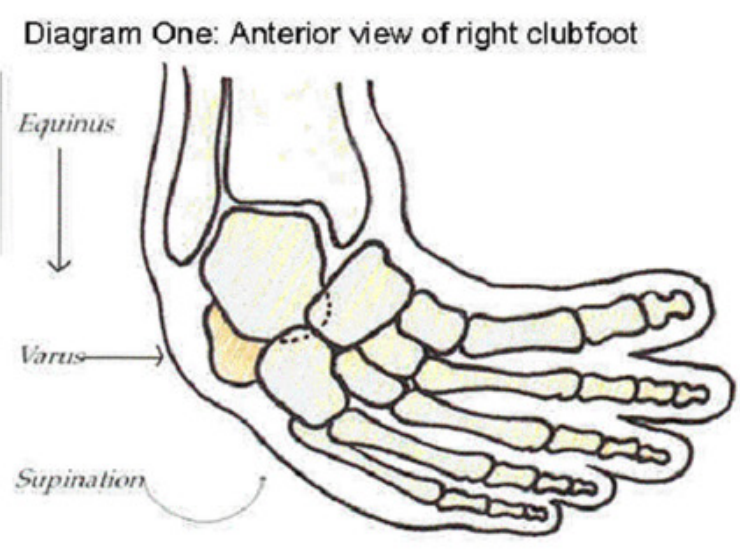

Figure 2: View of club foot.

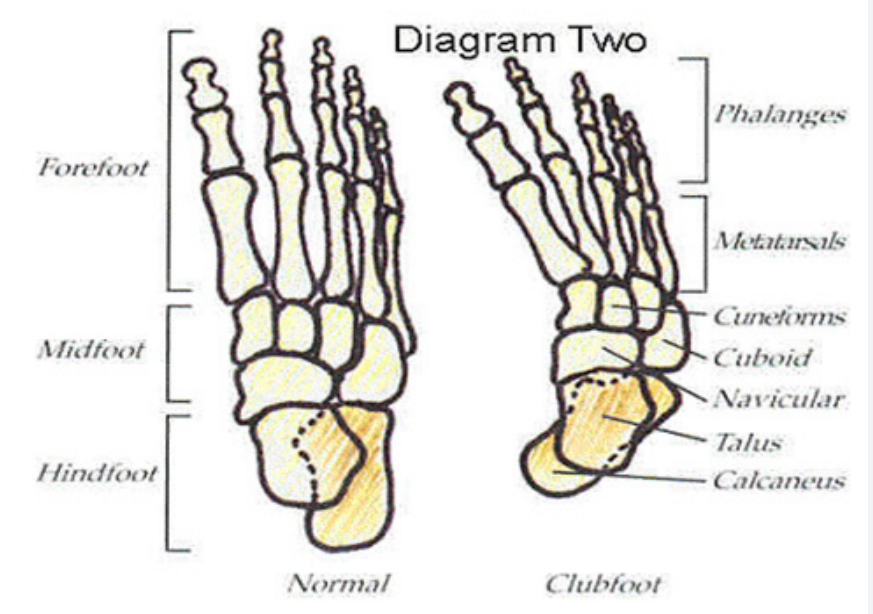

\section{Treatment}

A normal developing foot turns into a clubfoot during the second trimester of pregnancy. Clubfoot is not an embryonic abnormality. Treating successfully clubfoot and understanding the pathomechanics has always been unsolved point for modern medicine. Clubfoot is usually diagnosed immediately after birth simply by looking at the foot. Most Orthopaedic surgeons have agreed that the initial treatment of a clubfoot should be nonsurgical and start as soon as possible after birth [20].

Ponseti's Method of Treatment: Dr. Ignacio pioneered this method of treatment in the 1940's. Patient, after treating with surgical corrections may develop painful foot with left over defect over time. Then he seek to understand the functional and pathological anatomy of both the normal foot and club foot and his finding explore the Ponseti method. The Ponseti method is a specific method of casting, serial manipulation and surgery of cutting down the achillestendon i.e tenotomy [21,22]. Treatment is provided instantly after birth and leads to plaster casting and serial manipulation. The foot's ligament and tendon are starched and manipulated on the weekly basis followed by implementing the cast of soft fiberglass that helps to bring the ligament in its original position.

Denis Brown Bar is also helpful for treating the clubfoot, also known as the foot abduction orthosis or Denis Brown splint. It has dynamic bar that allows independent movement of each leg that resulting in improved bracing tolerance which make the patient comfortable $[23,24]$. The rotation of the shoes on the bar is set at around seventy degree of external rotation for the clubfeet and around forty degree of external rotation for the standard feet. The brace is tied up to the four years of age with time duration ofthree month including day and night. The first week after wearing braces the child required more attention and follow up to find out any complication. Client who does not get the adjustment with the braces in particular time periods can visit the orthopedician $[25,26]$.

Physician instructs the client for proper follow up at interval of one and three month and Range-of-motion exercises are advised to improve the flexibility. In some cases brace intolerance is one of the biggest reason for the reoccurrence of problem $[27,28]$. Reverting back of problem again treated with the repeat casting, followed by surgical procedure. Above the age of three years the child required only serial casting needed up to six weeks to facilitate muscle strengthening without using foot abduction brace, if accurate position is attained, the child undergone for next tibialis anterior tendon transfer to the third cuneiform (Figure 3).

\section{French Method}

French method is popular method of clubfoot treatment that also avoids extensive surgical treatment [29]. This method requires daily manipulations and stretching of the newborn clubfoot by providing two month regular treatment followed by immobilization with adhesive taping to maintain the correction. 
Even Machine was also used for stretching during the night time. Treatment frequency is decreased to further week and parents are advised for the use of splints in night and assist the child for exercise until the child reaches the walking age.

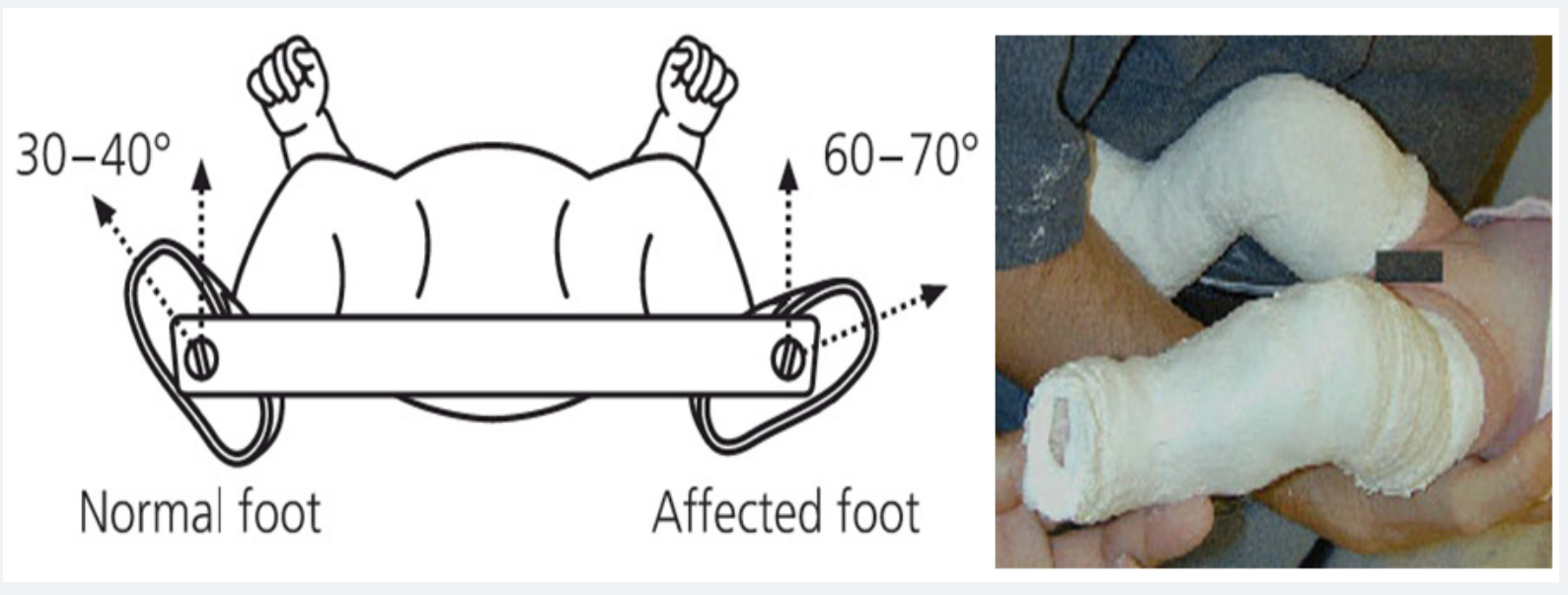

Figure 3: Foot abduction braces.

\section{Surgical Treatment of Clubfoot}

If the manipulation or serial casting treatment fails, surgery is required. The surgical correction is usually not done until the child is between six and nine months of age. Surgical treatment is performed to correct clubfoot and align the foot in original position. The surgical procedure usually consists of releasing and lengthening the tight tendons and joint capsule of the foot. Surgery almost takes 2 to 3 hours including the stay of two days for observation in hospital. Surgery required two incision and insertion of small pins to fix the correction of deformity. Pins are disconnected from the operation foot after four to six week of surgery and cast is placed for the time periods of eighty four days.

\section{Classification of Surgical Treatment}

i. Soft tissue releases that release the tight tendons/ ligament around the joints and result in lengthening of the tendons. This step is needed in approximately $30-50 \%$ of all treated clubfoot patients. Tendon transfers improve the tendons or ligaments in proper position.

ii. Osteotomies or arthrodeses are the procedure performed on bone. This method makes bone and joint more stabilize, to facilitate the bones to grow firmly.

Report shows that radial circumferential soft tissue release on medial, lateral, posterior and planar aspect of foot at an early age, obtained good results [30]. Soft tissue expander also helpful for the skin closure before going to operation.

\section{Conclusion}

The review article shows numerous ways to develop this deformity specially in children. Treatment is varied over the time including conservative and surgical procedures. Ponseti
Methods place good influence in correction of muscle, bone and joints abnormalities. Children will need follow-up on regular intervals for several years after treatment. Reoccurrence of problem may occur up to the end of growth age (18 years). So continuous follow up is recommended.

\section{References}

1. Wynne-Davis R (1964) Family studies and the causes of congenital clubfoot: Talipesequinovarus, talipes calcaneal valgus, and metatarsus varus. J Bone Joint Surg Br 46: 445-463.

2. Strach EH (1986) Clubfoot through the Centuries. Progress in Pediatric Surgery 20. Springer-Verlag 20: 215-237.

3. Ponseti IV, Smoley EN (1963) Congenital club foot: The results of treatment. J Bone Joint Surg Am 45-A: 261-344.

4. Grant AD, Atar AD, Lehman WB (1992) The Ilizarov technique in correction of complex foot deformities. Clin Orthop Relat Res 280: 94103.

5. Handelsman JE Badalamente MA (1981) Neuromuscular Studies in Clubfoot. J Pediatr Orthop 1(1): 23-32.

6. Ritsila VA (1969) Talipes equinovarus and Vertical Talus Produced Experimentally in Newborn Rabbits. Acta Orthop Scan Suppl 121: 1-98.

7. Stewart SF (1951) Clubfoot: Its Incidence, Cause and Treatment. Anatomical-Physiological Study. J Bone Joint Surg 33A(3): 557-590.

8. Wiley AM (1959) Clubfoot An Anatomical and Experimental Study of Muscle Growth. J Bone Joint Surg 41B: 821.

9. Irani RN, Sherman MS (1963) The Pathological Anatomy of Clubfoot. J Bone Joint Surg 45(1): 45-52.

10. Bleck EE (1993) Annotation of Clubfoot. Develop Med Child Neurol 35: 927-930.

11. Diaz VA, Diaz VJ (1984) Pathogenesis of Idiopathic Clubfoot. Clin Orthop185: 14-24.

12. Honein MA, Paulozzi LJ, Moore CA (2000) Family history, maternal smoking, and clubfoot: an indication of a gene-environment interaction. Am J Epidemiol 152: 658-665. 
13. Wynne-Davies R (1965) Family studies and aetiology of clubfoot. J Med Genet 2: 227-232.

14. Dimeglio A (1991) Classification of Congenital Talipes Equinovarus. 11(5): 329.

15. PJ Gibbons et al. (2013) Updates on clubfoot. J Paediatr Child Health 49(9): E434-E437.

16. Aggarwa Alok, Gupta Neha (1991) The Role of Pirani Scoring System in the Management and Outcome of Idiopathic Club Foot by Ponseti Method, International Journal of Science and Research 5(6): 2016.

17. Tachdjian MO (1985) The Child Foot. W.B. Saunders. Philadelphia, USA, pp. 139-239.

18. Thometz JG, Simons GW (1993) Deformity of the Calcaneocuboid Joint in Patients Who Have TalipesEquinovarus. J. Bone Joint Surg 75A(2): 190-195.

19. Beatson TR, Pearson JR (1966) A Method of Assessing Correction in Clubfoot. J Bone Joint Surg 48(1): 40-50.

20. Kite JH (1964) The Clubfoot. New York Grune and Stratton. Inc, USA.

21. Simons GW (1978) Analytical Radiography and the Progressive Approach in Talipes Equinovarus. Orthop Clin North Am 9(1): 187206.

22. Boehm S, Limpaphayom N, Alaee F, Sinclair MF, Dobbs MB (2008) Early results of the Ponseti method for the treatment of clubfoot in distal arthrogryposis. J Bone Joint Surg Am 90(7):1501-1507.
23. Chen RC, Gordon JE, Luhmann SJ, Schoenecker PL, Dobbs MB (2007) A new dynamic foot abduction orthosis for clubfoot treatment. J Pediatr Orthop 27:522-528.

24. Gurnett CA, Boehm S, Connolly A, Reimschisel T, Dobbs MB (2008) Impact of congenital talipesequinovarusetiology on treatment outcomes. Dev Med Child Neurol 50(7): 498-502.

25. Dobbs MB, Rudzki JR, Purcell DB, Walton T, Porter KR (2004) Factors predictive of outcome after use of the Ponseti method for the treatment of idiopathic clubfeet. J Bone Joint Surg Am 86-A(1): 22-27.

26. Gurnett CA, Boehm S, Connolly A, Reimschisel T, Dobbs MB (2008) Impact of congenital talipesequinovarusetiology on treatment outcomes. Dev Med Child Neurol 50: 498-502.

27. Changulani M, Garg NK, Rajagopal TS, Bass A, Nayagam SN, et al. (2006). Treatment of idiopathic club foot using the Ponseti method. Initial experience. J Bone Joint Surg Br 88: 1385-1387.

28. Morcuende JA, Dolan LA, Dietz FR, Ponseti IV (2004) Radical reduction in the rate of extensive corrective surgery for clubfoot using the Ponseti method. Pediatrics 113: 376-380.

29. Bensahel H, Catterall A, Dimeglio A (1990) Practical applications in idiopathic clubfoot: a retrospective multicentric study in EPOS. J Pediatr Orthop 10:186-188.

30. Mackay DW (1983) New concept of and approach to club foot treatment: Section II- Correction of Club Foot. J Pediatr Orthop 3: 1021.

\section{Your next submission with Juniper Publishers} will reach you the below assets

- Quality Editorial service

- Swift Peer Review

- Reprints availability

- E-prints Service

- Manuscript Podcast for convenient understanding

- Global attainment for your research

- Manuscript accessibility in different formats

( Pdf, E-pub, Full Text, Audio)

- Unceasing customer service

Track the below URL for one-step submission https://juniperpublishers.com/online-submission.php 